\title{
Early Growth of Improved Acacia mangium at Different Planting Densities
}

\author{
Arif Nirsatmanto \\ Center for Forest Biotechnology and Tree Improvement, \\ Jl. Palagan Tentara Pelajar Km. 15, Purwobinangun, Pakem, Sleman, Yogyakarta, Indonesia 55582
}

Received February 23, 2016/ Accepted June 13, 2016

\begin{abstract}
Integrating tree improvement into silvicultural practices is essential in forest plantation. Concerning this fact, Acacia mangium spacing trial planted using genetically improved seed was established in West Java. This study was aimed to evaluate the impact of ages and planting density on early growth of improved seed A. mangium in the spacing trial. Improved seed from 2 seed orchards (SSO-5 and SSO-20) and a control of unimproved seed from seed stand (SS-7) were tested together in spacing $3 \times 3 \mathrm{~m}$ and $2 \times 2 \mathrm{~m}$. Height, diameter, stem volume, and stand volume were observed at 3 ages. The results showed that improved seed consistently outperformed to unimproved seed. Ages were highly significant for all traits, but the significant difference varied among traits and seed sources for planting density and the interactions. High density performed better growth than low density at first year, and they were varied in subsequent ages depending on traits and seed sources. Improved seed from less intensity selection orchard was less tolerance to high density than that from high intensity selection orchard, but the tolerance was reversed in low density. Improved seed A. mangium from different level of genetic selection has responded differently in behavior to the changes of planting density.
\end{abstract}

Keywords: Acacia mangium, tree improvement, silviculture practices, spacing trial

*Correspondence author, email:arifnirsatmanto@biotifor.or.id, ph.: +62-274-895954/fax.:+62-274-896080

\section{Introduction}

A comprehensive tree improvement program for Acacia mangium was started in 1992 by establishing a series of firstgeneration seedling seed orchards in some regions of Indonesia. The genetic materials used in this program were collected from a wide range of natural populations, such as Papua New Guinea (PNG), Far North Queensland (FNQ), and Indonesia provenances (Hashimoto et al. 1996). Following to the breeding strategy, a series of secondgeneration progeny trials was then established in 2000 (Kurinobu \& Rimbawanto 2002). Genetically improved seed produced from seedling seed orchards of both generations have been used in plantation establishment in Indonesia. Realized genetic gain achieved through the first-generation tree improvement program has been also confirmed in genetic gain trials, i.e. 66-138\% increase in stand volume at 2 years of age and $58-81 \%$ at 4 years of age (Nirsatmanto et al. 2014); $13-30 \%$ increase in 8 years projected stand volume for un-thinned plantation (Kurinobu et al. 2006). In addition, hybridization of this species with $A$. auriculiformis has also shown potential to improve productivity with hybrids shown to be $17 \%$ more productive than their pure parents (Sunarti et al. 2013).

Understanding the impacts of tree improvement on silvicultural practices is particularly important for deployment of genetically improved seed in operational forest plantation. This is because improved genotypes may respond differently to the changes of silvicultural practices applied in operational plantations (McKeand et al. 1997). Planting density is one of the most important silvicultural decisions that is determined through spacing arrangement in the beginning of plantation establishment. Spacing influences many growth characteristics, cultivation techniques, harvesting practices, and volume production of a stand. In practice, the optimal spacing is determined by the species, the site, the end use of the wood, and possibly by the genetic quality of materials. Trees become dominant within a stand when their initial size, genetic characteristics, or resource availability enable them to grow faster, suppress their neighbors, and occupy additional growing space (Harrington et al. 2009). In a previous study, Kurinobu et al. (2006) also indicated that the amount of increases of genetic gain in A. mangium primarily depends on the genetic materials and the initial spacing. Considering this, a spacing trial of A. mangium was established in West Java using seed collected from genetically improved and unimproved sources.

The objectives of this present study is to evaluate the impact of ages and planting density on early growth of $A$. mangium which was planted in spacing trial using the improved seed resulted from a series tree improvement program. Results of this assessment are important for 
quantifying early growth of $A$. mangium plantation which is planted using seed derived from populations with different levels of genetic improvement. Its implication to operational management is also discussed to provide some indication as to how to use genetically improved seed for different silvicultural regimes.

\section{Methods}

Tested materials Genetically improved seed of $A$. mangium used in this study were collected from 2 seedling seed orchards, namely SSO-5 and SSO-20. Although the seed orchards originated from the same genetic resources (a mixture of Papua New Guinea (PNG) and Far North Queensland-Australia (FNQ) provenances) they were generated using a different selection strategy. The SSO-5 is a seedling seed orchard which was converted from a large progeny test consisting of 134 plus trees families (Nirsatmanto et al. 1994), while the SSO-20 is a composite seedling seed orchard, consisting of 40 top ranked families, which was established as a production population using a sub-line breeding strategy (Nirsatmanto 2012). The main difference in strategy among the orchards is the levels of selection intensity in genetic entries, i.e. less intensity selection for SSO-5 and high intensity for SSO-20.

The improved seed collected from the respective seed orchard were then used for establishing a spacing trial. As a comparison, unimproved seed collected from a local seed stand of Subanjeriji (namely SS-7), which is genetically less productive (Nirsatmanto et al. 2014) than the both seedling seed orchards, were also planted together in the trial.

Spacing trial The spacing trial was established in West Java, which is located at latitude of $\mathrm{S}^{\circ} 28^{\prime} 3^{\prime \prime}$, longitude of E107 $2{ }^{\circ} 59^{\prime \prime}$, and altitude of $438 \mathrm{~m}$ above sea level. The climate type is A according to Schmidt and Ferguson with an average temperature of $25^{\circ} \mathrm{C}$, and annual rainfall of 2,500 $\mathrm{mm}$ year $^{-1}$. The predominant types of soils are grumusols and the topography is sloped around 5\% (Nirsatmanto et al. 2015).

In each of the 4 replications, bulk seed collected from the 3 seed sources (SSO-5, SSO-20 and SS-7) were planted at each of 2 planting densities: 1,111 trees $\mathrm{ha}^{-1}$ as low density (spacing of $3 \times 3 \mathrm{~m}$ ) and 2,500 trees ha ${ }^{-1}$ as high density (spacing of $2 \times 2 \mathrm{~m}$ ), which allowed a comparison of low and high competition. The spacing trial was established in $30 \times$ $30 \mathrm{~m}$ plots in a randomized complete block design. Within each plot, trees were planted in square grid pattern which resulted a $10 \times 10$ tree square for low density and $15 \times 15$ tree square for high density.

The previous vegetation was an A. mangium stand. In site preparation, the area was cultivated manually through land clearing, followed by slashing without plowing. When planting, $100 \mathrm{~g}$ of TSP and $100 \mathrm{~g}$ of compost were applied per tree. In the years following planting, fertilizer was applied twice per year using $150 \mathrm{~g}$ tree ${ }^{-1}$ of NPK until 2 years of age. During the first year after planting, weed control was carried out manually every four months in order to eliminate the competition between weeds and the planted trees. The frequency of weeding was then reduced to twice a year at 2 and 3 years of age due to canopy closure which inhibited the development of grassy weeds.

Measurement and data analysis To eliminate competition differentials among the plots, only the inner 36 trees $(6 \times 6$ trees) for low density and 81 trees $(9 \times 9$ trees $)$ for high density in each plot were measured. During the first 3 years, trees planted in the spacing trial were assessed once per year for 4 traits (height, diameter at breast height, individual stem volume, and stand volume). Data on height and diameter were used to calculate individual stem volume $(v)$ using the volume equation as shown in Equation [1] (Inose et al. 1992)

$\dot{v}=0.000058806 \times D^{1,71772} \times H^{1.0809}$

Subsequently, the stand volume of each plot was calculated by summing up the individual stem volumes of all surviving trees in each plot, which was then expressed on a stand volume productivity per hectare $\left(\mathrm{m}^{3} \mathrm{ha}^{-1}\right)$ basis as shown in Equation [2]:

Stand volume per hectare $=\frac{\text { stand volume on plot }}{\text { area pf plot in square meter }} \times 10,000$ [2]

In this study, an analysis of variance for each trait was made separately at each of 3 seed sources: SSO-5, SSO-20 and SS7 , which was treated as three distinct experiments with reference to the 2 spacing. The analysis was done using plot mean data $\left(y_{i j k}\right)$ with the following linear model as shown in Equation [3].

$y_{i j k}=\mu+B_{i}+T_{j}+D_{k}+T D_{j k}+e_{i j k}$

note:

$\mu \quad=$ population mean

$B_{i}=$ the $i$ th replication effect

$T_{j}=$ the $j$ th age effect

$D_{k}=$ the $k$ th density effect

$T d_{j k}=$ the effect of age $\times$ density interaction

$e_{i j k}=$ experimental error associated with $y_{i j k}$, respectively

While in order to test the significance of differences among the seed sources, a combined analysis of variance over the three seed sources were made with the following linear model:

$y_{i j k l}=\mu+P_{i}+G_{j}+D_{k}+B l+G D_{j k}+G B_{j l}+D B k l+e_{i j k l}[4$

note:

$\mu \quad=$ population mean

$P_{i}=$ the $i$ th population (improved and unimproved seed) effect

$G_{j}=$ the $j$ th seed source within population effect

$D_{k}=$ the $k$ th density effect

$B_{l}=$ the $l$ th replication effect

$G d_{j k}=$ the effect of seed source $\times$ density interaction

$G b_{j l}=$ the effect of seed source $\times$ replication interaction

$D b_{k l}=$ the effect of density $\times$ replication interaction

$e_{i j k l}=$ experimental error associated with $y_{i j k l}$, respectively

\section{Results and Discussion}

Tree and stand growth Means for survival and 8 traits at 3 age measurements are given in Table 1. Although the survival decreased annually at a rate of around $10 \%$ during the 3 measurements, mostly due to wind damage, the 
differences in survival rate among the seed sources and among the 2 planting densities at each measurement was only around $1 \%$ to $6 \%$. Difference in survival was smaller than expected given the large difference in competition. This indicates that the differences in mortality were not the result of the difference in seed source and planting density.

$\mathrm{P}$-values obtained from the analysis of variance of the traits within each of the three seed sources are listed in Table 2 . As expected, stand ages was highly significant for all traits in all seed sources. The significant difference due to planting density and its interaction with age varied among the seed sources. However, they consistently showed significant differences for stand volume. The stand age $\times$ planting density interaction was significantly different for diameter at breast height (dbh), stand volume, dbh increment and stand volume increment. The development of the stands in the 2 planting densities can be observed in Figure 1. Most of the stand growth variables evaluated in this study were better in high density than at low density with the exception of stem volume. However as the stands aged, the changes of growth varied in absolute scale among the planting densities and the seed sources while they all had similar growth patterns.

Along the 3 ages, all seed sources showed fairly vigorous height growth in both planting densities, although productivity was much greater in the high density plots. Trees established at high planting density were consistently taller than those in the low density (Table 1). At 3 years, the average tree height for improved seed derived from 2 seed orchards reached $11.5 \mathrm{~m}$ in the high density plots, with the corresponding the average height growth in low density of less than $11 \mathrm{~m}$. The 2 improved seed orchards showed similar height growth in high density, but it was different at low density where SSO-5 was taller than SSO-20 (Figure 1A). The difference of height growth between high and low density for SSO-5 was smaller than that for SSO-20. The significance of differences was confirmed by analysis of variance (Table 2), where the height of trees at the 2 plantings density was not significantly different for SSO-5, while it was significantly different for SSO-20. Although the absolute scale of height growth was smaller what was observed for improved seed, the positive height growth response to high density was also confirmed in the unimproved seed from SS-7, where trees at high density were taller than at low density but not significant in SSO-5. In general it indicated that the increased of inter-tree competition due to higher planting density has stimulated faster early height growth of the improved seed of $A$. mangium.

Another fact observed in the present study regarding the height growth is that the height increment growth pattern between high and low planting density was different among the 3 seed sources, although the differences were not statistically significant (Table 2). The greater height increment at high density compared to low density for SSO-5 was consistent along the 3 measurements. Meanwhile the positive growth response to planting density steadily

Table 1 Mean of growth traits and stand volume for 3 seed source populations (SSO-5 and SSO-20 as improved seed population, and SS-7 as unimproved seed population) in 2 stand densities (high and low) at 3 years measurements

\begin{tabular}{|c|c|c|c|c|c|c|c|}
\hline \multirow{2}{*}{ Age } & \multirow{2}{*}{ Traits } & \multicolumn{2}{|c|}{ SSO-5 } & \multicolumn{2}{|c|}{ SSO -20} & \multicolumn{2}{|c|}{ SS-7 } \\
\hline & & High & Low & High & Low & High & Low \\
\hline \multirow[t]{9}{*}{1} & Height & 2.85 & 2.71 & 2.83 & 2.50 & 2.62 & 2.34 \\
\hline & Dbh & 2.77 & 2.37 & 2.81 & 2.14 & 2.60 & 1.90 \\
\hline & Stem volume $\left(\times 10^{-3} \mathrm{~m}^{3}\right)$ & 1.22 & 0.97 & 1.23 & 0.83 & 1.03 & 0.61 \\
\hline & Stand volume $\left(\mathrm{m}^{3} \mathrm{ha}^{-1}\right)$ & 2.75 & 1.00 & 2.90 & 0.82 & 2.29 & 0.57 \\
\hline & Height increment & 2.85 & 2.71 & 2.83 & 2.50 & 2.62 & 2.34 \\
\hline & Dbh increment & 2.77 & 2.37 & 2.81 & 2.14 & 2.60 & 1.90 \\
\hline & Stem volume increment $\left(\times 10^{-3} \mathrm{~m}^{3}\right)$ & 1.22 & 0.97 & 1.23 & 0.83 & 1.03 & 0.61 \\
\hline & MAI stand volume $\left(\mathrm{m}^{3} \mathrm{ha}^{-1}\right)$ & 2.75 & 1.00 & 2.90 & 0.82 & 2.29 & 0.57 \\
\hline & Survival $(\%)$ & 93 & 92 & 99 & 96 & 94 & 86 \\
\hline \multirow[t]{9}{*}{2} & Height & 8.97 & 8.58 & 8.86 & 7.74 & 8.37 & 7.16 \\
\hline & $\mathrm{Dbh}$ & 9.56 & 10.00 & 9.92 & 9.88 & 9.31 & 9.12 \\
\hline & Stem volume $\left(\times 10^{-3} \mathrm{~m}^{3}\right)$ & 29.97 & 29.98 & 30.86 & 24.86 & 26.32 & 20.28 \\
\hline & Stand volume $\left(\mathrm{m}^{3} \mathrm{ha}^{-1}\right)$ & 63.67 & 26.78 & 61.84 & 22.30 & 47.11 & 17.58 \\
\hline & Height increment & 6.13 & 5.87 & 6.02 & 5.24 & 5.75 & 4.82 \\
\hline & Dbh increment & 6.79 & 7.63 & 7.10 & 7.74 & 6.72 & 7.22 \\
\hline & Stem volume increment $\left(\times 10^{-3} \mathrm{~m}^{3}\right)$ & 28.75 & 29.00 & 29.62 & 24.03 & 25.29 & 19.67 \\
\hline & MAI stand volume $\left(\mathrm{m}^{3} \mathrm{ha}^{-1}\right)$ & 60.91 & 25.78 & 58.93 & 21.47 & 44.81 & 17.00 \\
\hline & Survival $(\%)$ & 84 & 78 & 80 & 81 & 73 & 81 \\
\hline \multirow[t]{9}{*}{3} & Height & 11.48 & 10.94 & 11.59 & 10.60 & 10.77 & 9.78 \\
\hline & Dbh & 11.40 & 13.58 & 11.99 & 13.51 & 11.65 & 12.64 \\
\hline & Stem volume $\left(\times 10^{-3} \mathrm{~m}^{3}\right)$ & 56.16 & 62.96 & 60.36 & 59.41 & 52.14 & 48.04 \\
\hline & Stand volume $\left(\mathrm{m}^{3} \mathrm{ha}^{-1}\right)$ & 99.49 & 53.41 & 103.47 & 49.93 & 84.61 & 39.45 \\
\hline & Height increment & 2.51 & 2.36 & 2.73 & 2.86 & 2.40 & 2.62 \\
\hline & Dbh increment & 1.84 & 3.58 & 2.07 & 3.63 & 2.33 & 3.51 \\
\hline & Stem volume increment $\left(\times 10^{-3} \mathrm{~m}^{3}\right)$ & 26.18 & 32.97 & 29.50 & 34.55 & 25.82 & 27.76 \\
\hline & MAI stand volume $\left(\mathrm{m}^{3} \mathrm{ha}^{-1}\right)$ & 35.82 & 26.63 & 41.63 & 27.63 & 37.50 & 21.87 \\
\hline & Survival (\%) & 71 & 74 & 70 & 76 & 66 & 75 \\
\hline
\end{tabular}




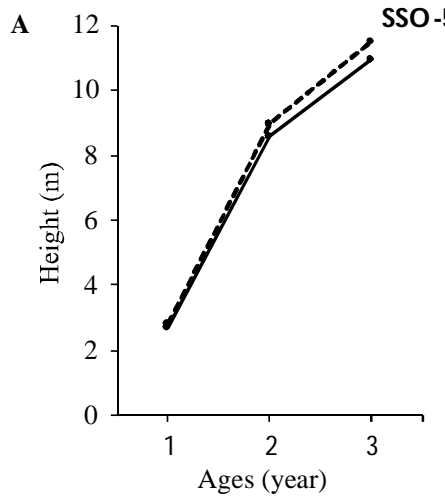

B

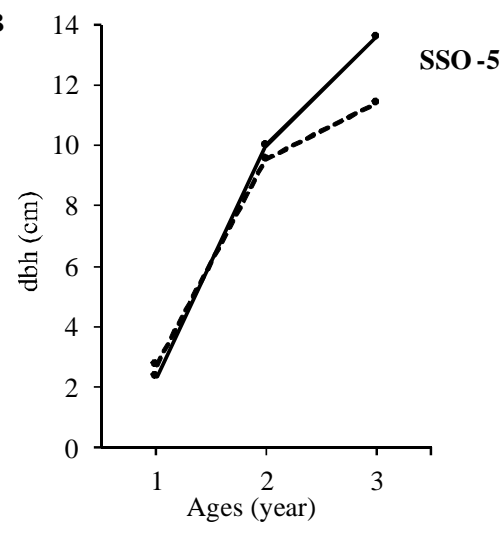

C
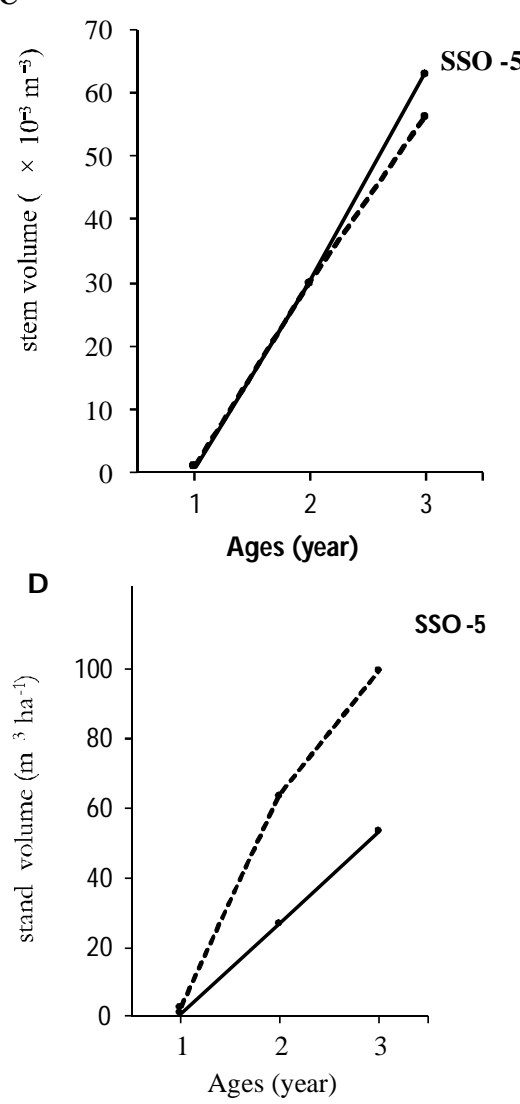
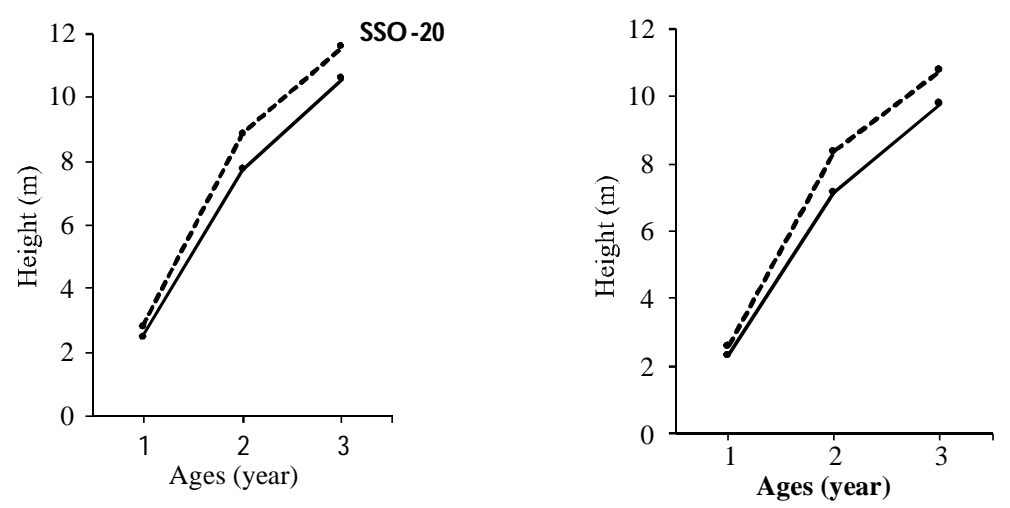

SS-7

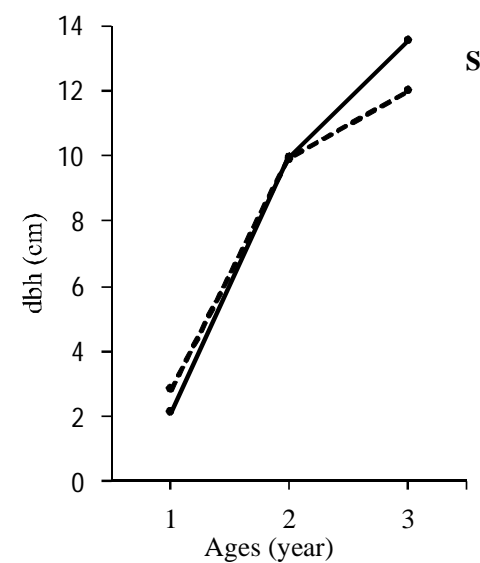

SSO -20

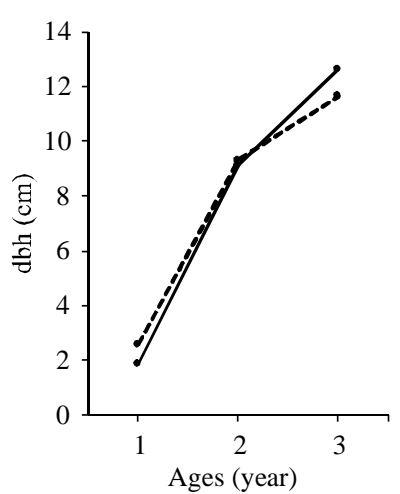

SS-7

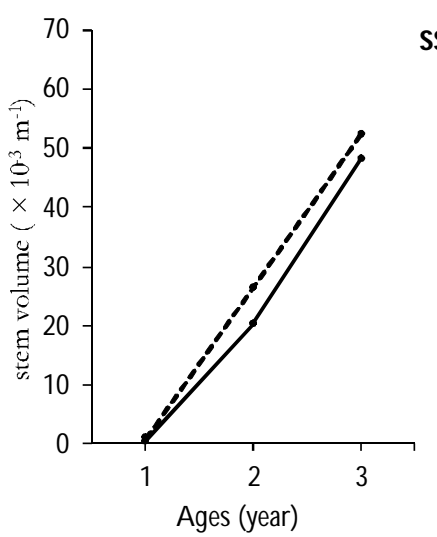

SS-7

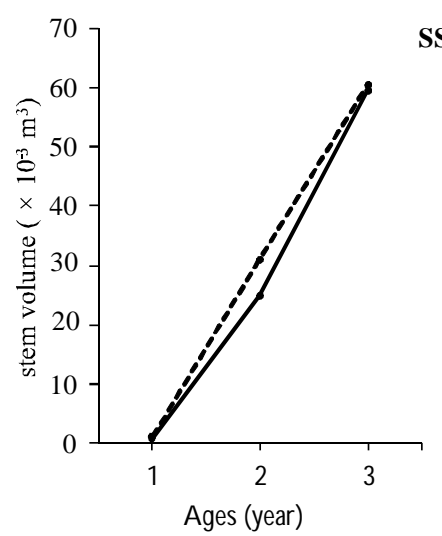

SSO-20

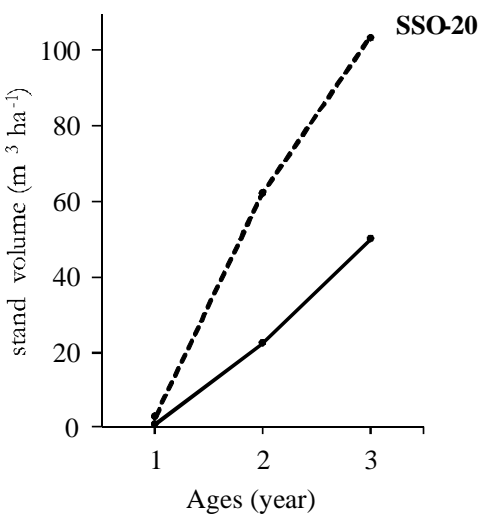

Figure 1 Development of growth in height (A), dbh (B), stem volume (C) and stand volume (D) of the three seed source populations (SSO-5 and SSO-20 as improved seed population, and SS-7 as unimproved seed population) in relation to the ages and stand density (high and low). High (_---..), low 
Table 2 Observed significance associated with the analysis of variance based on a plot mean basis for all traits in 3 seed source populations (SSO-5 and SSO-20 as improved seed population, and SS-7 as unimproved seed population)

\begin{tabular}{|c|c|c|c|c|c|c|c|c|c|}
\hline \multirow{3}{*}{$\begin{array}{l}\text { Source of } \\
\text { variance }\end{array}$} & \multirow{3}{*}{$d f$} & \multicolumn{8}{|c|}{$p$-value } \\
\hline & & \multirow[b]{2}{*}{ height } & \multirow[b]{2}{*}{$\begin{array}{l}\text { diameter } \\
\text { (dbh) }\end{array}$} & \multirow[b]{2}{*}{$\begin{array}{c}\text { Stem } \\
\text { volume }\end{array}$} & \multirow[b]{2}{*}{$\begin{array}{c}\text { Stand } \\
\text { volume }\end{array}$} & \multicolumn{4}{|c|}{ Increment } \\
\hline & & & & & & height & $\mathrm{dbh}$ & $\begin{array}{c}\text { Stem } \\
\text { volume }\end{array}$ & $\begin{array}{c}\text { Stand } \\
\text { volume }\end{array}$ \\
\hline \multicolumn{10}{|l|}{ SSO -5 } \\
\hline Density & 1 & 0.2236 & 0.0027 & 0.5085 & 0.0002 & 0.5844 & 0.0354 & 0.4663 & 0.0094 \\
\hline Age & 2 & $<.0001$ & $<.0001$ & $<.0001$ & $<.0001$ & $<.0001$ & $<.0001$ & $<.0001$ & $<.0001$ \\
\hline Density $*$ age & 2 & 0.8278 & 0.0007 & 0.6091 & 0.0098 & 0.9852 & 0.0450 & 0.5814 & 0.0411 \\
\hline \multicolumn{10}{|l|}{ SSO -20 } \\
\hline Density & 1 & 0.0097 & 0.0908 & 0.4117 & $<.0001$ & 0.3220 & 0.0978 & 0.9098 & 0.0004 \\
\hline Age & 2 & $<.0001$ & $<.0001$ & $<.0001$ & $<.0001$ & $<.0001$ & $<.0001$ & $<.0001$ & $<.0001$ \\
\hline Density*age & 2 & 0.4241 & 0.0003 & 0.6882 & 0.0004 & 0.5137 & 0.0255 & 0.3214 & 0.0060 \\
\hline \multicolumn{10}{|l|}{ SS-7 } \\
\hline Density & 1 & 0.0045 & 0.8574 & 0.2134 & $<.0001$ & 0.1894 & 0.2824 & 0.4943 & $<.0001$ \\
\hline Age & 2 & $<.0001$ & $<.0001$ & $<.0001$ & $<.0001$ & $<.0001$ & $<.0001$ & $<.0001$ & $<.0001$ \\
\hline Density*age & 2 & 0.2608 & 0.0207 & 0.6889 & $<.0001$ & 0.1814 & 0.0694 & 0.3049 & 0.0010 \\
\hline
\end{tabular}

diminished at the 3 years for the SSO-20 and SS-7 where at given age the height increment in high density was lower than that in low density (Table 1 ). The 3 years height increment of SSO-20 and SS-7 in high density were 2.73 and $2.40 \mathrm{~m}$, respectively, with the corresponding height increment in low density were $2.86 \mathrm{~m}$ for the SSO-20 and $2.62 \mathrm{~m}$ for the SS-7. The different result between SSO-5 and SSO-20 indicated that improved seed might show different growth responses to planting density in height increment, which was likely caused by the difference in the level of genetic selection.

In case of dbh, the early growth was slightly better in high density than those in low density for all seed sources. At the first year, dbh in high density reached around $2.8 \mathrm{~cm}$ for SSO-5 and SSO-20, and $2.6 \mathrm{~cm}$ for SS-7, with the corresponding dbh in low density plots around $2 \mathrm{~cm}$ for all seed sources. However, from 2 years, all stands showed a steadily decline of dbh growth increment in high planting density, and thus resulting smaller overall dbh than what was observed at low density. Although the dbh growth in low density plots between the 2 improved seed was similar, around $2 \mathrm{~cm}$ at first, $10 \mathrm{~cm}$ at 2 and $13.5 \mathrm{~cm}$ at 3 years, the change of response to high density was slightly different. The dbh in high density for SSO-5 seemed to decline earlier than in SSO-20, with the unimproved seed from SS-7 consistently as the slowest one (Figure $1 \mathrm{~B}$ ). The declined dbh for SSO-5 in high density was observed at 6 months earlier than SSO20. As a result, the difference in dbh among the 2 densities for SSO-5 was larger than those in SSO-20. The significant difference of dbh in SSO-5 was confirmed with results of analysis of variance as shown at Table 2. The large difference in dbh growth among the 2 planting densities steadily increased with the increasing of ages. Dicken \& Will (2004) stated that as stand age, convergence of wood production often occur between different stand densities because the growth rate in high density stands reach a maximum and begins to decline earlier than what is observed in lower density stands.

The earlier reduction of dbh growth in SSO-5 might be due to more intense inter-tree competition that occurred in high density plantings. The impact of negative response to planting density in SSO-5 increased with the increasing stand ages as indicated by the smaller of dbh growth at 3 years, which is not only compared to the SSO-20, but also to the unimproved seed of SS-7. The impact was also observed in distribution of $\mathrm{dbh}$, where the low density produced more trees of the larger dbh classes than the high density (Figure 2). Unlike SSO-5, the distribution of dbh classes among the 2 planting densities was relatively similar for improved seed of SSO-20 and unimproved seed of SS-7, although they showed different absolute mean value.

Regarding to dbh increment, all seed sources showed the same pattern of response to planting density, although the absolute scale of increment was different. The dbh increment was higher in high density plots in the first year and was then smaller in the 2 and 3 years compared to the low density (Table 1). Unlike the height growth, this result indicated the impact of the increased inter-tree competition due to high planting density reduced dbh growth. This is because $\mathrm{dbh}$ is a measure of tree size that is more sensitive to competition than tree height. If inter-tree competition in a stand appeared more intense, then the dbh increment tends to decrease.

By considering the facts that stem volume is a function of height and diameter, this study also revealed that there was different response to planting density in stem volume between the 2 seed orchards, although in each orchard the density effect was not statistically significant (Table 1). Along the 3 years of measurement, SSO-5 performed slightly better for stem volume than SSO-20 in low stand density (Figure $1 \mathrm{C}$ ). By contrast, SSO-20 performed better for stem volume and seemed more tolerance of the high planting density but not significantly different (Table 2). The unimproved seed of SS-7 also produced larger stem volume in high density than that in low density, although the absolute stem volume was smaller than the improved seed. The lower tolerance to high density for stem volume in SSO-5 was mainly due to the reflection of the change in diameter growth rather than in height growth. On the other hand, less tolerance to low density in SSO-20 was mainly due to the change in height growth. Thus, it could be considered that the significant difference of the traits between the 2 densities (Table 2) for both height and diameter led to smaller stem 
SSO- 5

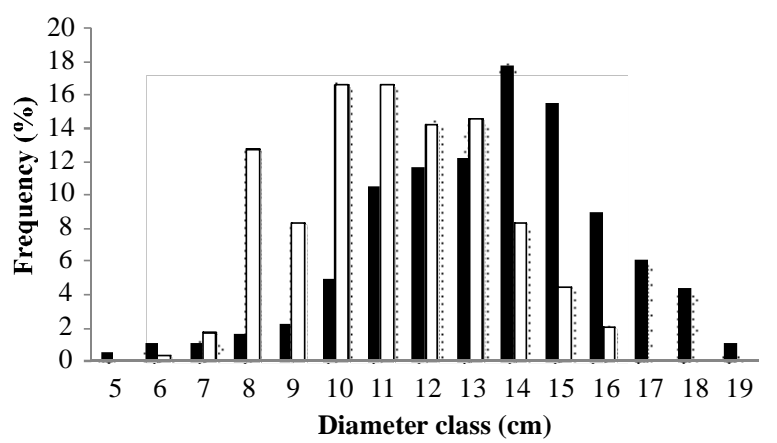

SB-20

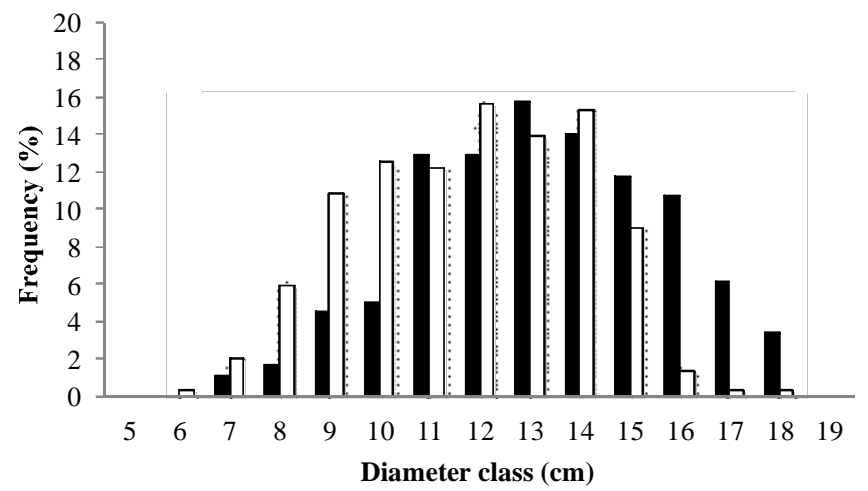

SS -7

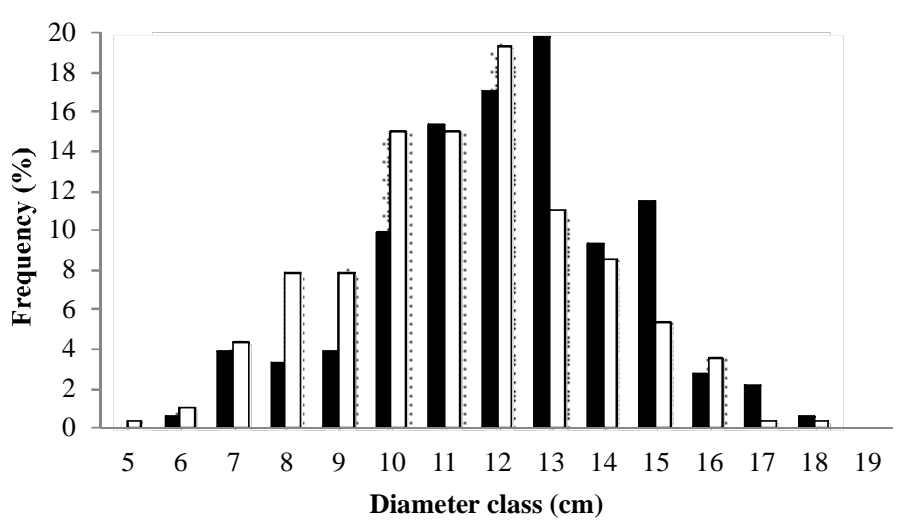

Figure 2 Diameter (dbh) distributions by spacing of the 3 seed source populations (SSO-5 and SSO-20 as improved seed population, and SS-7 as unimproved seed population) at 3 years of age. Low $(\boldsymbol{\square})$, high ( $\square)$.

volumes. Two years of age seemed to be the critical time to express the impact of inter-tree competition to the growth of stem volume for SSO-5. It was also confirmed with the notable reduction of stem volume increment at 2 years ages (Table 1). While for SSO-20 and SS-7, such critical time was observed at least at 1 year later over the SSO-5.

As expected, stand volume production in all seed sources were significantly greater in the high density than that in low density (Table 1). This is mainly due to the difference in number of trees planted in the 2 planting densities, where number of observed trees was greater at high density than at low density. However, with age the reduced diameter growth due to the intense inter-tree competition in high density might cause a reduction in their stand volume production. This is observed in SSO-5 where as the largest stand volume in high density at 2 years of ages, it declined to be the smaller than SSO-20 at 3 years of age due to the intense inter-tree competition, although it was still larger than the unimproved seed (Table 1). This reduction was also clearly observed in the MAI which was the largest at 2 years and declined to be the smallest one at 3 years of age, even if compared to the unimproved seed. According to Clutter et al. (1983), stand volume is not only related to the individual stem volume, but is also closely related to other factors such as diameter growth as well as stand density and site index. Therefore, despite not statistically different in stem volume between the high and low stand density in SSO-5, a sharp reduction in stand volume increment was attributed mainly to significantly differences in diameter (Table 1).

Genetic impacts The improved seed used in present study derived from 2 seedling seed orchards: SSO-5 and SSO-20, which were established using different levels of genetic selection. SSO-5 was converted from a large breeding population progeny test through rouging inferior families and trees within-families. Meanwhile, SSO-20 was composed of the top 10 families from each of 4 sub-lines originated from PNG and FNQ provenances, which is established as a part of production population through composite seedling seed orchard (Nirsatmanto 2012). The selection intensity in seed orchard for SSO-5 was much lower than that practiced in SSO-20. Thus, the genetic diversity of SSO-5 seemed much wider compared to that of SSO-20.

Concerning to the results of the preceding sections, the growth of the improved seed differed between the 2 planting densities and were consistently more productive than unimproved seed. In general, the improved seed derived from the 2 seed orchards: SSO-5 and SSO-20, showed better growth and volume than the unimproved seed derived from the seed stand (SS-7) at both planting densities (Table 1). The 
Table 3 Observed significance associated with the combined analysis of variance over the three seed source populations (SSO-5 and SSO-20 as improved seed population, and SS-7 as unimproved seed population) based on a plot mean basis for all traits at 1,2 and 3 years of age

\begin{tabular}{|c|c|c|c|c|c|c|c|c|c|}
\hline \multirow{3}{*}{ Source of variance } & \multirow{3}{*}{$d f$} & \multicolumn{8}{|c|}{$p$-value } \\
\hline & & \multirow[b]{2}{*}{ height } & \multirow{2}{*}{$\begin{array}{c}\text { diameter } \\
\mathrm{dbh}\end{array}$} & \multirow{2}{*}{$\begin{array}{c}\text { Stem } \\
\text { volume }\end{array}$} & \multirow{2}{*}{$\begin{array}{c}\text { Stand } \\
\text { Volume }\end{array}$} & \multicolumn{4}{|c|}{ Increment } \\
\hline & & & & & & height & $\begin{array}{l}\text { diameter } \\
\text { dbh }\end{array}$ & $\begin{array}{c}\text { Stem } \\
\text { volume }\end{array}$ & $\begin{array}{r}\text { Stand } \\
\text { volume }\end{array}$ \\
\hline \multicolumn{10}{|l|}{ Age 1 year } \\
\hline Population & 1 & 0.0017 & 0.0069 & 0.0028 & 0.0652 & 0.0017 & 0.0069 & 0.0028 & 0.0652 \\
\hline Seed sources (Population) & 1 & 0.0303 & 0.1494 & 0.1467 & 0.8503 & 0.0303 & 0.1494 & 0.1467 & 0.8503 \\
\hline D ensity & 1 & 0.0015 & 0.0004 & 0.0006 & 0.0003 & 0.0015 & 0.0004 & 0.0006 & 0.0003 \\
\hline Seed sources*density & 2 & 0.1428 & 0.1461 & 0.2020 & 0.6281 & 0.1428 & 0.1461 & 0.2020 & 0.6281 \\
\hline \multicolumn{10}{|l|}{ Age 2 year } \\
\hline Population & 1 & 0.0147 & 0.0386 & 0.0384 & 0.0357 & 0.0594 & 0.0942 & 0.0416 & 0.0373 \\
\hline Seed sources (Population) & 1 & 0.0784 & 0.7299 & 0.3139 & 0.4455 & 0.1727 & 0.3559 & 0.3203 & 0.4395 \\
\hline Density & 1 & 0.0082 & 0.7398 & 0.0933 & 0.0004 & 0.0317 & 0.0140 & 0.1119 & 0.0005 \\
\hline Seed sources*density & 2 & 0.2599 & 0.4873 & 0.3881 & 0.4957 & 0.4444 & 0.7116 & 0.3954 & 0.4978 \\
\hline \multicolumn{10}{|l|}{ Age 3 year } \\
\hline Population & 1 & 0.0283 & 0.0095 & 0.0251 & 0.0318 & 0.7361 & 0.6847 & 0.2019 & 0.4820 \\
\hline Seed sources (Population) & 1 & 0.6493 & 0.1896 & 0.9497 & 0.9576 & 0.2329 & 0.6868 & 0.5143 & 0.5922 \\
\hline Density & 1 & 0.0289 & 0.0001 & 0.8431 & 0.0003 & 0.7817 & 0.0031 & 0.1621 & 0.0408 \\
\hline Seed sources*density & 2 & 0.7359 & 0.0301 & 0.3517 & 0.6934 & 0.7901 & 0.6383 & 0.7694 & 0.8283 \\
\hline
\end{tabular}

performance of the seed orchard seed over the seed stand was consistent across all 3 ages. A combined analysis of variance over the 3 seed sources and the 2 planting densities revealed that the growth between improved seed population and unimproved seed population over the 2 densities were significantly different for height, dbh, stem volume, and stand volume, except for stand volume in the first year age (Table 3). This result indicated that improvement resulted from breeding $A$. mangium was also confirmed in the plantation with different planting density. This result was in agreements with the reports of the previous genetic gain trial, where improved seed derived from a breeding program of $A$. mangium was generally better in stand growth than the unimproved stand (Kurinobu et al. 2006; Hastanto 2010; Nirsatmanto et al. 2014).

The improved seed from SSO-5 seemed to be less tolerance to high stand density which was clearly confirmed with the reduced stem volume in high density plots from 2 years of age (Table 1 and Figure $1 \mathrm{C}$ ) although the stem volume was not statistically significant among the 2 densities (Table 2). In contrast, the improved seed from SSO-20 was more tolerant of high density, but produced lower stem volumes at low density. The different behavior of the improved seed in these 2 stand densities could be interpreted as differential expression of genetic improvement at different planting densities. This indicated that the differences in genetic selection practiced in the seed orchard had produced the improved seed that responded differently to planting density.

Genetically, there are 2 possible explanations for the discrepancy between the growth at each planting density. Firstly, the heterogeneous genetic resources selected from the best plus trees families which composed of seed orchard for SSO-20 had increased inter-provenances out-crossing in the seedling seed orchard. The out-crossing that occurred among the elite plus trees families in the orchards would consequently lead to more improved seed which may be more tolerance to inter-tree competition and high planting density. Therefore, the more improved seed performed better when planted at a closer spacing. White et al. (2007) reported that a large portion of elite selections are likely to be able to tolerate higher levels of competition. Secondly, the less competitive ability of SSO-5 at high density might be due to low level of family and within-family selections practiced in the orchard. This is because selection intensity practiced in SSO-5 was much smaller than that of SSO-20, which included some suppressed trees that may possess high genetic potential if planted in the less competitive environment. As a result, improved seed produced from such kind seed orchard would be expected to grow well in the absence of competition such as in wide spacing or open grown condition (Ye et al. 2010).

Management implications Control of density at stand establishment or by thinning and other silviculture treatment is an important aspect of timber management (Clutter et al. 1983). As a fast growing species, the density at establishment of A. mangium plantation should be considered with care as the early growth of stands is strongly influenced by the spacing at planting. Better understanding of this phenomenon could lead to increase stand productivity which are established using genetically improved seed from varies seed sources. This is because different level of genetic improvement might affect the different responses to changes in competitive environments, such as stand density (Ye et al. 2010).

The results of present study showed that there was a clear impact of age and planting density on stand growth in 
genetically improved and unimproved stands of A. mangium. There are two implications considering this result for management practices in the establishment of A. mangium plantations. Firstly, at 2 planting densities, the improved seed tended to be less tolerant to higher density along the rotation. This is due to more intense inter-tree competition, particularly for diameter growth which started to decline at around 2 years of age. Although the high stand density $(2 \times 2$ $\mathrm{m})$ used in present study was higher than that used in operational plantations for pulpwood production (typically 2 $\times 3 \mathrm{~m}$ ), the early declines in stand growth are likely to be the same. On the other hand, the higher stand density in present study would produce twice as much volume $\left(\mathrm{m}^{3} \mathrm{ha}^{-1}\right)$ compared to the lower stand density. Given this differential impact of high density, decisions on planting density should be made with an understanding of the whole management aspects including harvesting and thinning scenarios, and the destined uses of the wood as well. This is because the increases of growth through the uses of genetically improved seed might drastically decrease with the increase of within stand competition at a later age. As hypothesized by Hamilton Jr. and Rehfeldt (1994), the increased individual growth rates may lead to excessive stand density which in turn results in lower stand volume increments later in the rotation.

Secondly, the early growth response to different planting density varied among the improved seed from 2 different seed orchards, although they showed consistently better stand growth productivity compared to the unimproved seed. In practice, if the plantations are established using the improved seed collected from SSO-5, which was derived from a low level of selection intensity, wider spacing in initial planting is likely to be better than close spacing for early stand development. Meanwhile, where the plantation require a higher stand density, using seed collected from SSO-20, which is derived from an orchard of higher genetic selection intensity, would be better due to its greater tolerance to intertree competition. The growth of trees derived from 2 seed orchards as tested in the present study indicated that each of the orchards had merits for operational plantation management.

\section{Conclusion}

The impacts of age and planting density on the early growth of genetically improved seed of A. mangium were observed in this spacing trial. Stand age provided highly significant differences for all growth traits assessed. Higher planting density has stimulated faster early height growth of the improved seed, but the response was different for stem volume and diameter. Genetically improved seed of $A$. mangium derived from two different levels of genetic selection responded differently to the changes in competition caused by different planting densities. Seed from a seed orchard selected at a high selection intensity tended to be more tolerant to higher planting densities than seed from an orchard selected at a lower selection intensity. Although total stand volume per hectare for the improved seed of $A$. mangium in high density stands was consistently greater, a rapid decline of diameter growth due to the intense inter-tree competition might cause a serious reduction in the stand volume productivity as stand ages. Therefore, further decisions to use the more improved seed in higher planting density for plantation establishment should be balanced with other management aspects such as planting expenses, harvesting and thinning scenarios, destined uses of the wood and the length of the rotation.

\section{Acknowledgement}

We would like to express our sincere gratitude to PERHUTANI, on whose land the trial is established, for establishing and maintaining of the trial. We thank acacia and eucalyptus's research team in BBPPBPTH for all the fieldwork and data collections.

\section{References}

Clutter JL, Fortson JC, Pienaar LV, Britster GH, Bailey RL.1983. Timber Management: Quantitative Approach. New York: John Willey \& Sons.

Dickens ED, Will RE. 2004. Planting density impacts on slash pine stand growth, yield, product class distribution, and economics. In: Dickens ED, Barnett JP, Hubbard WG, Jokela EJ, Editors. Slash Pine: Still Growing and growing! Proceeding of The Slash Pine Symposium; Jekyll Island, Georgia. General Technical Report SRS-76 April 23-25, 2002. Ashevile: Department of Agriculture, Forest Service, Southern Research Station. pp.36-44.

Hamilton Jr. DA, Rehfeldt GE. 1994. Using individual tree growth projection models to estimate stand-level gains attributable to genetically improved stock. Forest Ecology Management 68:189-207. http://dx.doi.org/10.1016/ 0378-1127(94)90045-0.

Hastanto H. 2010. Peran benih unggul untuk meningkatkan produktivitas hutan tanaman Acacia mangium di PT. Musi Hutan Persada (in Indonesian). In: Leksono B, Widyatmoko AYPBC, Nirsatmanto A, Editors. Prosiding Ekspose Hassil-Hasil Penelitian: Status Terkini Penelitian Pemuliaan Tanaman Hutan Oktober 1 2009. Yogyakarta: Balai Besar Penelitian Bioteknologi dan Pemuliaan Tanaman Hutan. pp. 136-146.

Harrington TB, Harrington CA, DeBell DS. 2009. Effects of planting and site quality on 25-year growth and mortality relationships of Douglas-fir (Pseudotsuga menziesii var. menziesii). Forest Ecology Management 258:18-25. http://dx.doi.org/10.1016/j.foreco.2009.03.039.

Hashimoto K, Kurinobu S, Suhaendi H. 1996. Establishment of seed sources of tropical tree species in Indonesia. In : Dieters MJ, Matheson AC, Nikles DG, Harwood CE, Walker SM, Editors. Tree improvement for sustainable tropical forestry. Proceeding of the QFRI-IUFRO Conference. Caloundra: 27 October-1 November 1996. pp.370-371.

Inose M, Saridi Z, Nakamura T. 1992. Growth analysis of Acacia mangium. Hoppo Ringyo 2(2):17-19.

Kurinobu S, Rimbawanto A. 2002. Genetic improvement of 
plantation species in Indonesia-Summary of Project Achievement (JICA Forest Tree Improvement Phase II). In: Rimbawanto A, Susanto M. Editors. Proceeding of international conference on advances in genetic improvement of tropical tree species. Yogyakarta: Centre for Forest Biotechnology and Tree Improvement. October $1-3,2002$.

Kurinobu S, Arisman H, Leksono B, Hardiyanto EB. 2006. An impact of genetic improvement on the plantation management of Acacia mangium assessed by a growth model with size-density relationship. In: Mason E, Rimbawanto A, Ginoga KL, Hendromono, Komar TE Editors. Proceeding of International Seminar on Plantation Forest Research and Development, 21-23 November 2005. Yogyakarta: Centre for Plantation Forest Research and Development. pp. 120-124.

McKeand S, Crook RP, Allen HL. 1997. Genotypic stability effects on predicted family responses to silvicultural treatments in loblolly pine. Southern Journal of Applied Forestry 21(2):84-89.

Nirsatmanto A. 2012. Genetic variation observed in composite seedling seed orchard of Acacia mangium Wild at Central Java, Indonesia: Implications for increasing genetic gain and seed production. Journal of Forestry Research 9(2):91-99.http://dx. doi.org/10.20886/ijfr.v9i2.

Nirsatmanto A, Setyaji T, Wahyuningtyas RS. 2014. Realized genetic gain and site $\mathrm{x}$ seed sources interaction on stand volume productivity of Acacia mangium. Indonesian Journal of Forestry Research1(1):21-32. http://dx. doi.org/10.20886/ijfr.v1i1.

Nirsatmanto A, Setyaji T, Sunarti S, Kartikaningtyas D. 2015. Genetic gain and projected increase in stand volume from two cycles breeding program of Acacia mangium. Indonesian Journal of Forestry Research 2(2):21-32. http://dx. doi.org/10.20886/ijfr.v2i2.

Sunarti S, Na'iem M, Hardiyanto EB, Indrioko S. 2013. Breeding strategy of Acacia hybrid (Acacia mangium $\times$ A. auriculiformis) to increase forest plantation productivity in Indonesia. Jurnal Manajemen Hutan Tropika 19(2):128-137. http://dx. doi.org/10.7226/jtfm.19.2.128

White TW, Adams WT, Neale DB. 2007. Forest Genetics. Wallingford: $\mathrm{CAB}$ International.

Ye TZ, Jayawickrama KJS, St. Clair JB. 2010. Realized gain from Block-Plot Coastal Douglas-Fir trials in the Northern Oregon Cascades. Silvae Genetica 59(1):29-39. 